\title{
APLIKASI ASTAXANTHIN DARI HAEMATOCOCCUS PADA BENIH KERAPU SUNU (Plectropomus leopardus) TERHADAP TOTAL KAROTENOID DAN PROFIL DARAH
}

\author{
Daniar Kusumawati ${ }^{\#}$, Ketut Mahardika, dan Ketut Maha Setiawati \\ Balai Besar Riset Perikanan Budidaya Laut dan Penyuluh Perikanan \\ JI. Br. Gondol Ds. Penyabangan Kec. Gerokgak Kab. Buleleng, Kotak Pos 140, Singaraja, Bali 81155
}

(Naskah diterima: 26 Februari 2019; Revisi final: 8 Agustus 2019; Disetujui publikasi: 8 Agustus 2019)

\begin{abstract}
ABSTRAK
Haematococcus merupakan alga yang kaya karotenoid dari jenis astaxanthin yang tidak hanya berpotensi sebagai sumber pigmen merah tetapi juga sebagai antioksidan. Aplikasi haematococcus telah dilakukan pada larva kerapu sunu dan menunjukkan adanya perbaikan peformansi warna merah yang cukup signifikan. Tujuan dari penelitian ini adalah mengetahui pengaruh haematococcus sebagai sumber astaxanthin terhadap pertumbuhan, total karotenoid, dan profil darah (hematokrit dan haemoglobin) pada juvenil ikan kerapu sunu. Benih kerapu sunu ukuran panjang rata-rata $14,07 \pm 0,07 \mathrm{~cm}$ dan bobot rata-rata 45,92 $\pm 6,35 \mathrm{~g}$ dipelihara dalam jarring berukuran $0,5 \mathrm{~m} \times 0,5 \mathrm{~m} \times 1 \mathrm{~m}$ yang diletakkan dalam bak beton ukuran $3 \mathrm{~m} \times$ $1,2 \mathrm{~m} \times 1,2 \mathrm{~m}$. Kepadatan ikan tiap jaring adalah lima ekor. Perlakuan yang diujicobakan adalah penambahan haematococcus ke dalam pakan buatan dengan dosis dan kompisisi sebagai berikut: A) 1\%dari berat pakan, B) $1 \%$ dari berat pakan + 10\% minyak ikan, dan C) $0 \%$ (kontrol). Hasil penelitian menunjukkan bahwa penambahan haematococcus ke dalam pakan tidak memberikan perbedaan nyata terhadap pertumbuhan mutlak panjang dan bobot, serta laju pertambahan panjang dan bobot ( $P$ value $>0,05$ ). Penambahan haematococcus memberikan perbedaan nyata $(P$ value $<0,05)$ terhadap konversi pakan di mana perlakuan $A(1,99 \pm 0,09) ; B(2,12 \pm 0,14) ;$ dan C $(2,28 \pm 0,09)$. Penambahan haematococcus memberikan peningkatan terhadap akumulasi kandungan total karoten, hematocrit, dan haemoglobin darah.
\end{abstract}

\section{KATA KUNCl: kerapu sunu; haematococcus; total karoten; profil darah}

ABSTRACT: The application effects of astaxanthin from haematococcus on total carotenoid and blood profile of coral trout grouper seed. By: Daniar Kusumawati, Ketut Mahardika, and Ketut Maha Setiawati

Haematococcus, an alga rich in carotenoids of the astaxanthin type, not only has the potential as a source of red pigment but also as an antioxidant. The purpose of this study was to determine the effects of hematococcus as astaxanthin source on the growth, total carotenoids, and blood profile (hematocrit and hemoglobin) of coral trout grouper juvenile. Coral trout grouper seed with an average length of $14.07 \pm 0.07 \mathrm{~cm}$ and an average weight of 45.92 $\pm 6.35 \mathrm{~g}$ were maintained in a net cagemeasuring $0.5 \mathrm{~m} \times 0.5 \mathrm{~m} \times 1 \mathrm{~m}$ placed in a $3 \mathrm{~m} \times 1.2 \mathrm{~m} \times 1.2$ m concrete tank. Fish density per net was five fish. The treatment tested was the addition of haematococcus into the artificial feed with the following dosages and compositions: A) $1 \%$ of the weight feed, B) $1 \%$ of the weight feed $+10 \%$ fish oil, C) $0 \%$ (control). The results showed that the addition of haematococcus to the feed did not give a significant difference to the absolute growth of length and weight and also specific growth and length rate ( $P$-value $>0.05)$. The addition of haematococcus gave a significant difference ( $P$-value $<0.05)$ to feed conversion ratio between treatment $A, B$ and $C$ with the values of $1.99 \pm 0.09,2.12 \pm 0.14$, and $2.28 \pm 0.09$, respectively. The addition of haematococcus also increased the levels of total carotene content, hematocrit, and hemoglobin. This study suggests that the application of haematococcus could significantly improve the red color performance of trout grouper larvae.

KEYWORDS: coral trout; haematococcus; total carotene; blood profile

\footnotetext{
\# Korespondensi: Balai Besar Riset Perikanan Budidaya Laut dan

Penyuluh Perikanan. JI. Br. Gondol Ds. Penyabangan

Kec. Gerokgak Kab. Buleleng, Kotak Pos 140, Singaraja, Bali

81155, Indonesia

Tel.: + 36292272

E-mail: ornamental_research@yahoo.co.id
} 


\section{PENDAHULUAN}

Carotenoid merupakan sekelompok pigmen alami yang di sintesis dari tanaman tingkat tinggi, lumut, alga, bakteria, dan fungi (Goodwin, 1980), yang bertanggung jawab terhadap pigmen merah, jingga, dan kuning (Britton et al., 2012). Terdapat lebih dari 400 jenis senyawa carotenoid yang ada di alam, namun hanya beberapa senyawa saja yang dimanfaatkan secara komersial antara lain $\beta$-carotene (Olaizola, 2003), astaxanthin, lutein, lycopene, canthaxanthin zeaxanthin, dan bixin (Tay-Agbozo et al., 2018). Carotenoid secara komersial dimanfaatkan sebagai pewarna alami pada makanan (Arimboor et al., 2015), sebagai bahan aditif pada makanan ternak (Mclnerney et al., 2016) dan ikan (AbdelsameeGoda et al., 2018); sebagai suplemen makanan (Graham \& Roser, 2000; Hussein et al., 2016), obat (Nolan et al., 2018), dan kosmetik (Kim et al., 2009). Selain sebagai sumber pigmen alami, carotenoid juga memiliki aktivitas antioksidan (Fiedor $\&$ Burda, 2014).

Haematococcus pluvialis merupakan mikroalga air tawar yang kaya akan karotenoid dari jenis astaxanthin (Shah et al., 2016). Haematococcus mampu menghasilkan astaxanthin sebanyak $1,5 \% 3 \%$ berat kering lebih tinggi 3,75-7,5 kali dari phafia yeast (Lorenz \& Cysewski, 2000). Astaxanthin memiliki dua chiral center dan terdapat dalam tiga bentuk stereoisomer (3S, 32 S); (3R, 32 S), dan (3R, 32 R) (Yang et al., 2013). Astaxanthin pada haematococcus didominasi dalam bentuk 3S, 3'S yang memiliki fungsi aktif sebagai sumber pigmen merah sekaligus memiliki aktivitas antioksidan lebih besar daripada vitamin $\mathrm{E}$ ( $\alpha$ tocopherol), $\beta$ carotene, lutein (Naguib, 2000). Antioksidan merupakan senyawa yang dapat memperlambat atau menghambat terjadinya kerusakan sel akibat radikal bebas melalui peredaman aktivitas radikal bebas atau memutus rantai reaksi oksidasi yang disebabkan oleh radikal bebas. Penggunaan senyawa antioksidan sintetik saat ini mendapat perhatian serius karena bersifat merugikan dan karsinogen (Sultana et al., 2007). Oleh karena itu, haematococcus dapat digunakan sebagai kandidat senyawa antioksidan dan agen pigmentasi yang alami dan aman untuk diaplikasikan pada ikan.

Pemanfaatan carotenoid dari haematococcus telah dilakukan untuk tujuan perbaikan peforma warna merah pada larva kerapu sunu (Kusumawati \& Setiawati, 2017). Peforma warna merah pada ikan kerapu sunu hasil budidaya cenderung mengalami pemudaran jika dibandingkan performa asli di alam. Perlakuan pemberian bahan berkaroten dari raw material jenis Haematococcus pluvialis (NatuRose) terbukti mampu memperbaiki pigmentasi warna merah pada kerapu sunu stadia larva. Tujuan dari penelitian ini adalah mengetahui pengaruh haematococcus sebagai sumber astaxanthin terhadap pertumbuhan, total karotenoid, dan profil darah (hematokrit dan hemoglobin) pada juvenil ikan kerapu sunu.

\section{BAHAN DAN METODE}

\section{Ikan Uji}

Ikan yang digunakan dalam penelitian ini adalah ikan kerapu sunu ukuran panjang rata-rata 14,07 \pm $0,07 \mathrm{~cm}$ dengan bobot rata-rata 45,92 $\pm 6,35 \mathrm{~g}$ yang merupakan hasil perbenihan di hatcheri Balai Besar Riset Budidaya Laut dan Penyuluhan Perikanan (BBRBLPP). Sebanyak 45 ekor benih ikan kerapu sunu diaklitimasi dalam bak persegi panjang berukuran 3 $\mathrm{m} \times 1,2 \mathrm{~m} \times 1,2 \mathrm{~m}$ selama satu minggu sebelum digunakan.

\section{Pakan Uji}

Pakan uji yang digunakan adalah pakan komersial dari brand otohime. Selanjutnya, pakan uji ditambahkan karoten dari jenis Haematococcus pluvialis komersil (NatuRose ${ }^{\mathrm{TM}}$ ). Kandungan astaxanthin dalam haematococcus berkisar 1,5\%dengan persentase total karotenoid terdiri dari 70\%monoester astaxanthin, 10\%diester astaxanthin, 5\%free astaxanthin, dan 15\% mengandung campuran â carotene, canthaxanthin, lutein, dan jenis carotenoid lain. Selain karotenoid, haematococcus (NatuRose ${ }^{\mathrm{TM}}$ ) juga mengandung protein, lemak, karbohidrat, dan berbagai jenis vitamin (Tabel 1, 2). Penambahan haematococcus sesuai dosis dilakukan dengan cara mencampur bahan dengan telur hingga membentuk emulsi. Emulsi yang terbentuk dicampurkan ke dalam pakan pelet hingga tercampur rata kemudian pakan dikeringanginkan pada suhu ruang. Pakan kontrol hanya diberikan telur sebagai binder.

\section{Perlakuan}

Perlakuan yang diujicobakan adalah penambahan bahan karoten komersial dengan dosis sebagai berikut: A) $1 \%$ dari berat pakan, B) $1 \%$ dari berat pakan $+10 \%$ minyak ikan, dan C) $0 \%$ (kontrol). Masing-masing perlakuan terdiri atas tiga ulangan. Pakan diberikan dua kali sehari sekenyangnya, dan dilakukan penghitungan pakan yang dikonsumsi pada tiap harinya. Ikan dipelihara pada jaring berukuran $0,5 \mathrm{mx}$ $0,50 \mathrm{~m} \times 1 \mathrm{~m}$ dengan kepadatan lima ekor per jaring. Jaring ditempatkan dalam bak beton berukuran $3 \mathrm{~m} \mathrm{x}$ $1,2 \mathrm{~m} \times 1,2 \mathrm{~m}$. Penelitian dilakukan selama tiga bulan di dalam gedung pemeliharaan (indoor). Pemeliharaan dilakukan dengan sistem air mengalir dalam kondisi salinitas air laut normal 33-34 ppt. 
Tabel 1. Kandungan nutrisi pada haematococcus (NatuRose ${ }^{\mathrm{TM}}$ ) (Sumber: www.ruscom.com)

Table 1. Nutrition content of haematococcus (NatuRose ${ }^{\mathrm{TM}}$ ) (Courtesy: www.ruscom.com)

\begin{tabular}{lccc}
\hline & Minimun & $\begin{array}{c}\text { Maksimum } \\
\text { Maximum }\end{array}$ & $\begin{array}{c}\text { Rata-rata } \\
\text { Mean }\end{array}$ \\
\hline Protein & 17.30 & 27.16 & 23.62 \\
Karbohidrat (Carbohydrates) & 36.9 & 40.0 & 38.0 \\
Lemak (Fat) & 7.14 & 21.22 & 13.80 \\
Besi//ron (\%) & 0.14 & 1.0 & 0.73 \\
Air/M oisture & 3.0 & 9.00 & 6.0 \\
Magnesium (\%) & 0.85 & 1.4 & 1.14 \\
Kalsium/Calcium (\%) & 0.93 & 3.3 & 1.58 \\
Biotin (mg/Lb) & 0.108 & 0.665 & 0.337 \\
L-carnitine (ug/g) & 7.0 & 12 & 7.5 \\
Folic acid (mg/100g) & 0.936 & 1.48 & 1.30 \\
Niacin (mg/Lb) & 20.2 & 35.2 & 29.8 \\
Pantothenic acid (mg/Lb) & 2.80 & 10.57 & 6.14 \\
Vitamin B1 (mg/Lb) & 0.050 & 4.81 & 2.17 \\
Vitamin B2 (mg/Lb) & 5.17 & 9.36 & 7.67 \\
Vitamin B6 (mg/Lb) & 0.659 & 4.5 & 1.63 \\
Vitamin B12 (mg/Lb) & 0.381 & 0.912 & 0.549 \\
Vitamin C (mg/Lb) & 6.42 & 82.7 & 38.86 \\
Vitamin E (mg/Lb) & 58.4 & 333 & 186.1 \\
Abu (Ash) & 11.07 & 24.47 & 17.71 \\
Soluble dietary fiber (\%) & - & - & 1.2 \\
Insoluble dietary fiber (\%) & - & - & 16.7 \\
\hline
\end{tabular}

Tabel 2. Kandungan asam amino haematococcus (NatuRose ${ }^{\mathrm{TM}}$ )

Table 2. Amino acid content of haematococcus (NatuRose ${ }^{T M}$ )

\begin{tabular}{lccc}
\hline & $\begin{array}{c}\text { Minimun } \\
\text { Minimun value }\end{array}$ & $\begin{array}{c}\text { Maksimum } \\
\text { Maximum value }\end{array}$ & $\begin{array}{c}\text { Rata-rata } \\
\text { Mean }\end{array}$ \\
\hline Tryptophan & 0.05 & 0.56 & 0.31 \\
Aspartic acid & 1.37 & 2.31 & 1.89 \\
Threonine & 0.78 & 1.24 & 1.04 \\
Serine & 0.73 & 1.06 & 0.94 \\
Glutamic acid & 1.70 & 2.39 & 2.19 \\
Proline & 0.69 & 1.00 & 0.89 \\
Glycine & 0.84 & 1.32 & 1.17 \\
Alanine & 1.30 & 1.92 & 1.73 \\
Cysteine & 0.16 & 0.21 & 0.19 \\
Valine & 0.83 & 1.94 & 1.36 \\
Methionine & 0.32 & 0.43 & 0.40 \\
Isoleucine & 0.55 & 0.97 & 0.79 \\
Leucine & 1.21 & 1.84 & 1.67 \\
Tyrosine & 0.40 & 0.63 & 0.52 \\
Phenylalanine & 0.61 & 1.05 & 0.90 \\
Histidine & 0.48 & 0.76 & 0.61 \\
Lysine & 0.75 & 1.32 & 1.13 \\
Arganine & 0.81 & 1.34 & 1.07 \\
\hline
\end{tabular}




\section{Pertumbuhan Ikan}

Sampling pertumbuhan ikan dilakukan setiap bulan pada seluruh populasi yang dipelihara. Parameter yang diamati antara lain panjang dan bobot benih yang kemudian diestimasikan dalam bentuk pertumbuhan mutlak dan laju pertambahan panjang dan bobotnya. Pertumbuhan mutlak panjang (L) dan bobot (W) dirumuskan sebagai berikut:

$$
L=\frac{L t-L o}{t}
$$

di mana:

$\mathrm{L}_{0}=$ panjang awal,

$L_{t}=$ panjang pada hari $t$

$\mathrm{t}=$ waktu

$$
W=\frac{W t-W_{0}}{t}
$$

di mana:

$\mathrm{W}_{0}=$ bobot awal

$\mathrm{W}_{\mathrm{t}}=$ bobot pada waktu $\mathrm{t}$

$\mathrm{t}=$ waktu

Laju pertambahan panjang (SLR) dan bobot (SGR) dirumuskan sebagai berikut:

$$
\mathrm{SLR}=\frac{\overline{\mathrm{Lt}}-\overline{\mathrm{LO}}}{\mathrm{t}} \times 100 \%
$$

di mana:

Lt = panjang rata-rata pada waktu t

LO = panjang rata-rata pada awal penelitian

$$
\mathrm{SGR}=\frac{\ln \overline{\mathrm{Wt}}-\ln \overline{\mathrm{W}_{0}}}{\mathrm{t}}
$$

di mana:

Wt $=$ bobot rata-rata pada waktu t

$\mathrm{W} 0=$ bobot rata-rata pada awal penelitian

\section{Profil Darah}

Profil darah yang diamati meliputi hematokrit dan haemoglobin yang dilakukan pada akhir penelitian. Pengambilan sampel darah dilakukan pada akhir penelitian dengan jumlah sampel tiga individu pada masing-masing perlakuan. Darah dilakukan pada bagian pangkal ekor dengan syringe $1 \mathrm{~mL}$ yang sebelumnya telah dibilas dengan larutan heparin sebagai antikoagulan. Sampel darah yang terkumpul ditempatkan ke dalam microtube $(2 \mathrm{~mL})$. Pengukuran hematokrit darah dilakukan dengan menggunakan capillary tube yaitu sampel darah dimasukkan ke dalam capillary tube hingga batas warna merah kemudian ditekan untuk menutup lubang tube. Sampel darah pada capillary tube disetrifus (setrifuge $\mathrm{H}-1.200 \mathrm{~m}$ ) dengan kecepatan 12.000 rpm selama lima menit. Persentase hematokrit diukur dengan menggunakan sliding cursor. Sedangkan, pengukuran hemoglobin dilakukan dengan menggunakan alat pengukur $\mathrm{Hb} \mathrm{HemoCue} \mathrm{Hb}$ $201^{+}$(Angelholm Sweden). Korelasi nilai haematokrit dan haemoglobin dihitung dan disajikan dalam bentuk grafik.

\section{Total karotenoid}

Analisis total karotenoid dilakukan di Laboratoriun Pusat Studi Pangan dan Gizi di Gedung Pusat Antar Universitas (PAU) Universitas Gadjah Mada, Yogyakarta dengan metode Spektrofotometer.

\section{HASIL DAN BAHASAN}

Pertumbuhan mutlak kerapu sunu menunjukkan garis linear positif di mana dengan bertambahnya umur maka akan semakin meningkat panjang (Gambar 1A) dan bobot ikan (Gambar 1C). Pertumbuhan panjang dan bobot mutlak kerapu sunu pada masing-masing perlakuan mulai awal pemeliharaan hingga akhir pemeliharaan tidak menunjukkan perbedaan yang signifikan, namun demikian, pada perlakuan C menunjukkan adanya peningkatan bobot mutlak yang lebih tinggi dibandingkan dengan perlakuan A dan B (Gambar 1C).

Berdasarkan pertumbuhan mutlak panjang dan bobot ikan, laju pertambahan panjang (Gambar 1B) dan bo bot (Gambar 1D) pada masing-masing perlakuan menunjukkan laju pertambahan yang semakin lambat terlihat dari grafik yang cenderung makin menurun. Pada perlakuan A menunjukkan perbedaan pada bulan kedua pemeliharaan di mana laju pertambahan panjang maupun bobot mengalami peningkatan kemudian mengalami penurunan secara drastis di bulan ketiga.

Pada masing-masing perlakuan tidak menunjukkan adanya perbedaan yang signifikan $(P>0,05)$ terhadap pertumbuhan mutlak panjang (L) dan bobot (W), serta laju pertambahan panjang (SLR) dan bobot (SGR). Akan tetapi, perlakuan A menunjukkan efisiensi pakan (FCR) yang paling baik $(P<0,05)$ dibandingkan dengan perlakuan B dan C (Tabel 3). Berdasarkan hasil analisis total karoten, hematokrit, dan hemoglobin menunjukkan bahwa perlakuan $A$ menunjukkan nilai yang paling tinggi diikuti dengan perlakuan $B$ dan $C$ (Gambar 2).

Pertumbuhan bobot maupun panjang pada ikan selalu mengikuti grafik eksponensial positif yaitu pertumbuhan akan semakin meningkat namun pada suatu titik tertentu (fase dewasa) pertumbuhan akan stabil dengan garis grafik mendatar (Effendie, 1997). Sementara itu, laju pertambahan bobot dan panjang menunjukkan kecepatan suatu organisme untuk 

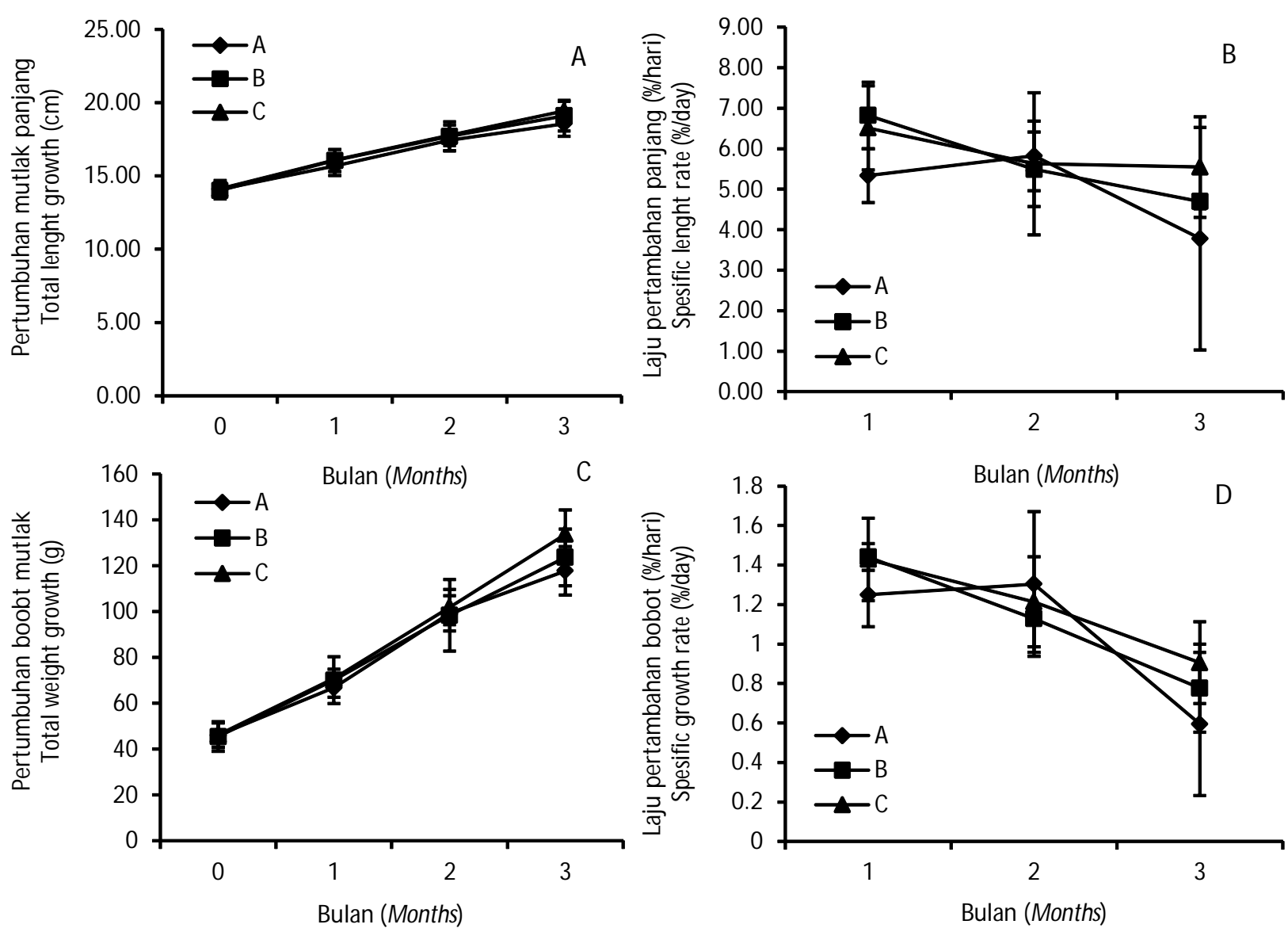

Gambar 1. Tren pertumbuhan panjang (A) dan bobot mutlak (C), serta laju pertambahan panjang (B) dan bobot (D) pada setiap bulan.

Figure 1. Trend of total length growth $(A)$ and total weight growth $(C)$, and spesific length rate $(B)$ and spesific growth rate (D).

Tabel 3. Pertumbuhan panjang (L) dan bobot mutlak (W), laju pertambahan panjang (SLR) dan bobot (SGR), dan konversi pakan rata-rata (FCR) selama penelitian

Table 3. Total length growth and weight growth, specific length rate and growth rate, and average feed conversion during the study

\begin{tabular}{|c|c|c|c|c|c|c|}
\hline & \multicolumn{2}{|c|}{ A } & \multicolumn{2}{|c|}{ B } & \multicolumn{2}{|c|}{ C } \\
\hline & $\begin{array}{c}\text { Rata-rata } \\
\text { Mean }\end{array}$ & $\begin{array}{c}\text { Standar } \\
\text { deviasi } \\
\text { Deviation } \\
\text { standard }\end{array}$ & $\begin{array}{l}\text { Rata-rata } \\
\text { Mean }\end{array}$ & $\begin{array}{c}\text { Standar } \\
\text { deviasi } \\
\text { Deviation } \\
\text { standard }\end{array}$ & $\begin{array}{l}\text { Rata-rata } \\
\text { Mean }\end{array}$ & $\begin{array}{c}\text { Standar } \\
\text { deviasi } \\
\text { Deviation } \\
\text { standard }\end{array}$ \\
\hline $\begin{array}{l}\text { Panjang } \\
\text { Length }(\mathrm{cm})\end{array}$ & $4.48^{\mathrm{a}}$ & 0.64 & $5.10^{\mathrm{a}}$ & 0.57 & $5.31^{\mathrm{a}}$ & 0.46 \\
\hline $\begin{array}{l}\text { Laju pertambahan panjang (\%/hari) } \\
\text { Specific length rate/SLR (\%day) }\end{array}$ & $4.98^{\mathrm{a}}$ & 0.71 & $5.67^{\mathrm{a}}$ & 0.63 & $5.90^{\mathrm{a}}$ & 0.51 \\
\hline $\begin{array}{l}\text { Bobot } \\
\text { Weight }(g)\end{array}$ & $20.69^{\mathrm{a}}$ & 1.81 & $24.60^{\mathrm{a}}$ & 3.83 & $24.50^{\mathrm{a}}$ & 1.41 \\
\hline $\begin{array}{l}\text { Bobot mutlak (\%hari) } \\
\text { Specific growth rate/SGR (\%/day) }\end{array}$ & $1.05^{\mathrm{a}}$ & 0.07 & $1.12^{\mathrm{a}}$ & 0.05 & $1.18^{\mathrm{a}}$ & 0.06 \\
\hline $\begin{array}{l}\text { Konversi pakan } \\
\text { Feed conversion ratio (FCR) }\end{array}$ & $1.99^{\mathrm{b}}$ & 0.09 & $2.12^{\mathrm{ab}}$ & 0.14 & $2.28^{\mathrm{a}}$ & 0.09 \\
\hline
\end{tabular}

Keterangan: Notasi dengan huruf yang sama pada masing-masing baris menunjukkan tidak berbeda nyata $(P>0,05)$ Note: $\quad$ The same letter notation in each in shows no significantly different (P.0.05) 

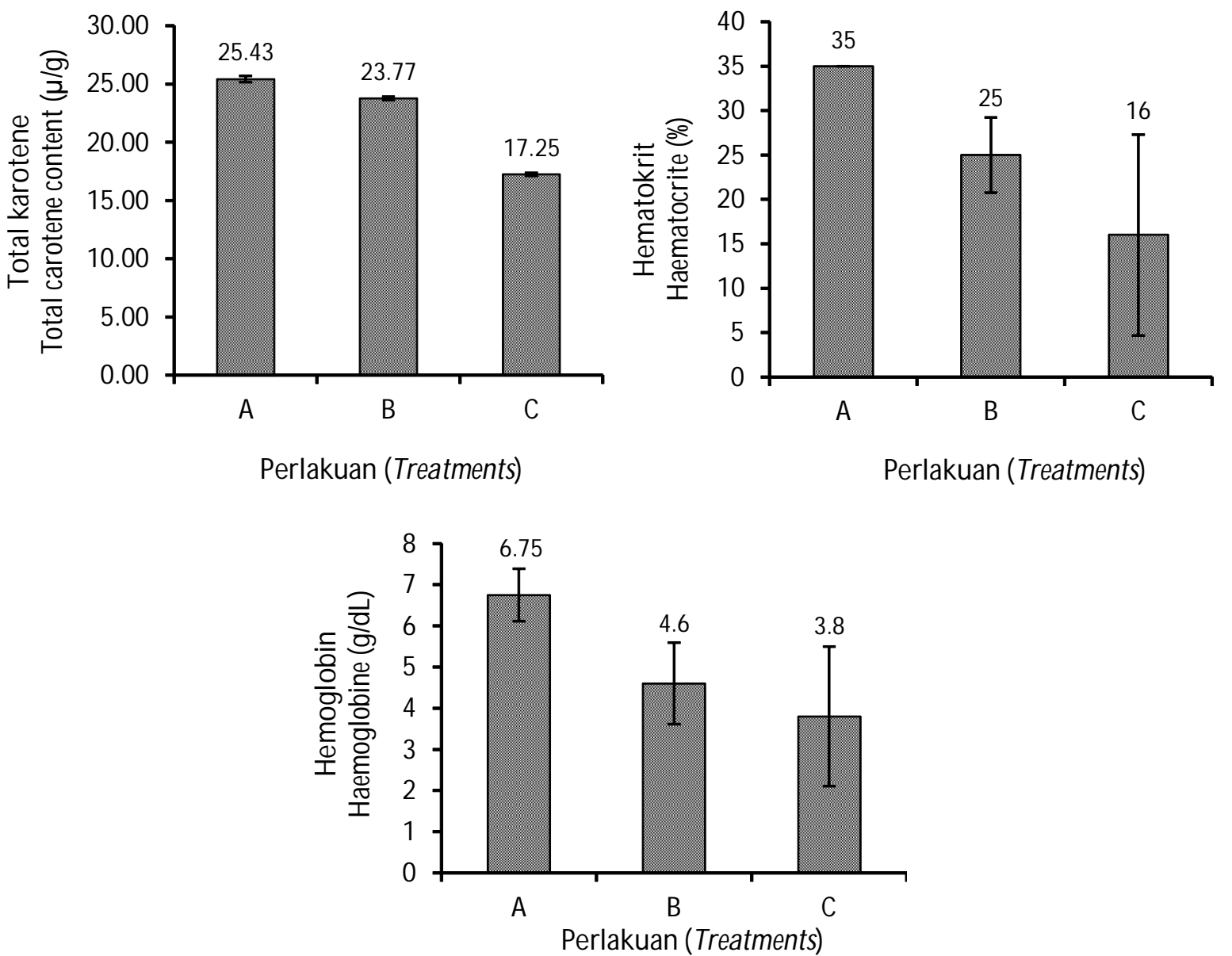

Gambar 2. Total karoten, kadar hematokrit, dan haemoglobin pada benih ikan kerapu sunu $(n=3$ ind.).

Figure 2. Total carotene, hematocrit, and hemoglobin levels in coral trout grouper seed at the end of study $(n=3$ ind.).

tumbuh baik panjang maupun bobot dalam satuan waktu tertentu. Pola grafik pertumbuhan dengan laju pertumbuhan berbanding tebalik dengan pertumbuhan, di mana pola grafik akan semakin menurun (eksponensial negatif) hingga pada fase dewasa laju pertambahan akan stabil (tidak mengalami pertambahan). Pernyataan tersebut tergambar dalam penelitian ini di mana pertumbuhan bobot dan panjang semakin meningkat, namun laju pertambahan bobot dan panjang akan semakin menurun. Perlakuan A yaitu perlakuan penambahan haematococcus pada pakan menunjukkan pola grafik yang berbeda dari perlakuan yang lain, di mana pada bulan kedua pemeliharaan menunjukkan reaksi positif yaitu laju pertumbuhan panjang maupun bobot makin meningkat dan memasuki bulan ketiga menunjukkan penurunan sama halnya dengan perlakuan yang lain. Penambahan haematococcus pada awal hingga bulan kedua pemeliharaan menunjukkan respons yang positif. Hal ini menunjukkan bahwa nutrisi yang terkandung dalam haematococcus (Tabel 1 dan 2) mampu mendorong percepatan peningkatan laju pertambahan panjang dan bobot pada awal pemeliharaan.

Hasil penelitian menunjukkan bahwa pemberian haematococcus tidak memberikan pengaruh nyata terhadap pertumbuhan mutlak dan laju pertambahan panjang maupun bobot. Namun demikian, pemberian haematococcus tanpa penambahan minyak ikan 10\% (perlakuan A) memberikan nilai efisiensi pakan yang paling baik dibandingkan dengan ikan yang diberi perlakuan penambahan haematococcus dan minyak ikan (perlakuan B) dan kontrol (perlakuan C). Hal ini menunjukkan penambahan haematococcus ke dalam ransum pakan ikan kerapu sunu memberikan pengaruh positif. Haematococcus tidak hanya mengandung astaxanthin namun juga memiliki kandungan nutrisi esensial lain yang diperlukan oleh tubuh ikan seperti 
protein, lemak, berbagai vitamin, dan mineral (NatuRose ${ }^{\mathrm{TM}}$ ). Kebutuhan untuk pertumbuhan ikan memerlukan kombinasi asam amino, asam lemak, vitamin, dan mineral yang sesuai untuk mendukung pertumbuhan ikan (Pangkey, 2011).

Perlakuan A juga memberikan hasil yang jauh lebih baik dengan meningkatkan sebesar 1,07x dan 1,47x akumulasi kandungan total karoten lebih tinggi dalam tubuh ikan dibandingkan dengan perlakuan B dan C. Berdasarkan data tersebut, nampaknya penambahan minyak ikan sebanyak 10\% dari bobot pakan justru menghambat penyerapan karotenoid ke dalam tubuh ikan. Sesungguhnya karotenoid merupakan jenis bahan yang bersifat hidrofobik atau sulit terlarut dalam lingkungan air, namun mudah terlarut dalam lemak. Berdasarkan hal tersebut, dapat diketahui bahwa tingkat lipid atau lemak dalam pakan dapat memberikan pengaruh positif dalam pelarutan karoten sehingga memudahkan penyerapan dalam tubuh seperti halnya percobaan dengan menggunakan level lipid yang berbeda akan memberikan pengaruh linear positif terhadap penyerapan karotenoid pada ikan raibow trout (Nickell \& Bromage, 1998; Yi et al., 2014). Perbedaan respons yang terjadi dapat dikarenakan adanya proses pembuatan pakan, di mana pada penelitian ini penggunaan minyak ikan sebagai sumber lipid dilakukan dengan melapisi pelet komersial yang telah ada kemudian ditambahkan dengan haematococcus. Sementara pada penelitian yang telah dilakukan oleh Nickell \& Bromage (1998), pembuatan pakan dilakukan dengan menambahkan minyak ikan ke dalam campuran pakan formulasi yang kemudian dibentuk menjadi pelet. Terkait dengan metode pembuatan pakan ini, nampaknya haematococcus yang diberi minyak ikan akan mudah lepas ke dalam air mengingat metode pengkayaan yang dilakukan hanya dengan cara dicampurkan di permukaan pakan. Hal inilah yang menyebabkan efek yang minyak ikan dalam penelitian ini kurang memberikan pengaruh yang optimal terhadap peningkatan total karotenoid pada benih kerapu sunu.

Penambahan haematococcus ke dalam pakan terbukti mampu memberikan pengaruh pada profil darah yaitu haematokrit dan haemoglobin pada ikan kerapu sunu. Perlakuan A memberikan peningkatan nilai haematokrit sebesar 1,4x dan 2,19x lebih tinggi, serta haemoglobin sebesar 1,47x dan 1,78x lebih tinggi dibandingkan dengan perlakuan $B$ dan C. Kisaran normal haematokrit dan haemaglobin pada kerapu sunu belum diteliti secara pasti, dan setiap spesies ikan memiliki kisaran normal haematokrit dan haemaglobin yang berbeda-beda. Kisaran normal nilai haematokrit pada ikan mas yang dipelihara dalam kondisi lingkungan standar adalah 28\%35\% (Munkittrick \& Leatherland, 1983), sementara itu, pada ikan salmon Atlantic (Salmo salar) berkisar 44\%49\% (Sandnes et al., 1988), dan pada ikan kerapu sunu yang dipelihara dalam salinitas 34 ppt berkisar $31 \pm 1,41 \%$ (Setiawati et al., 2017). Berdasarkan informasi tersebut membuktikan bahwa pemberian haematococcus mampu mempertahankan kondisi normal haematokrit darah kerapu sunu di mana pada perlakuan tanpa haematococcus level haematocrit sangat rendah yaitu $16 \%$ Kisaran normal haemoglobin pada darah ikan tawar yaitu ikan mas, nila, kowan, dan lele dumbo berkisar 5,05-8,33 g/dL pada jantan dan 5,22-7,03 g/dL pada betina (Salasia et al., 2001); sementara itu, pada ikan kerapu sunu pada kondisi salinitas 34 ppt memiliki kisaran normal haemoglobin 7,4 $\pm 0,57 \mathrm{~g} / \mathrm{dL}$ (Setiawati et al., 2017). Hal ini bersesuaian dengan pernyataan $\mathrm{Hrubec} \&$ Smith (2000) bahwa kadar normal hemoglobin pada ikan akuatik umumnya 5-10 g/dL. Berdasarkan info tersebut dapat diketahui bahwa penambahan haematococcus tanpa minyak mampu mempertahankan kadar haemoglobin ikan kerapu sunu pada kondisi yang normal secara umum yaitu $6,75 \mathrm{~g} / \mathrm{dL}$; sementara itu, pada perlakuan haematococcus yang dicampur minyak ikan dan kontrol memiliki kadar haemoglobin yang rendah yaitu masingmasing 4,6 g/dL dan 3,8 g/dL.

Pengukuran nilai haematokrit dan haemoglobin (haematology) merupakan salah satu metode untuk mengukur stres respons oleh karena perubahan lingkungan (Davis \& Parker, 1990) dan serangan penyakit (Jones \& Grutter, 2005) terhadap kesehatan ikan. Hematokrit menggambarkan persentase sel darah merah terhadap total volume darah (Meyer et al., 1992). Nilai hematokrit dipengaruhi oleh ukuran dan jumlah eritrosit. Hemoglobin merupakan protein yang mengandung senyawa besi hemin. Hemoglobin merupakan bagian dari sel darah merah yang mengikat oksigen dari insang untuk dihantarkan ke seluruh jaringan tubuh (Fánge, 1992). Kadar hemoglobin ( $\mathrm{Hb})$ dalam darah ikan berkaitan dengan jumlah eritrosit. Hal ini tergambar pada nilai hematokrit dan hemoglobin pada ikan kerapu sunu di mana berkorelasi linear positif (Gambar 3) di mana pada nilai hematokrit tinggi kadar hemoglobin juga tinggi dan sebaliknya. Hal ini dinyatakan pula oleh Fujaya (2004) yang meyatakan bahwa terdapat korelasi yang erat antara haematokrit dan hemoglobin di mana semakin rendah jumlah sel-sel darah merah maka semakin rendah pula kandungan hemoglobin dalam darah. Pernyataan tersebut diperkuat oleh pernyataan Fakharzadeh et al. (2011), yang membuktikan bahwa nilai hematokrit ikut berpotensi dalam membawa oksigen dan 


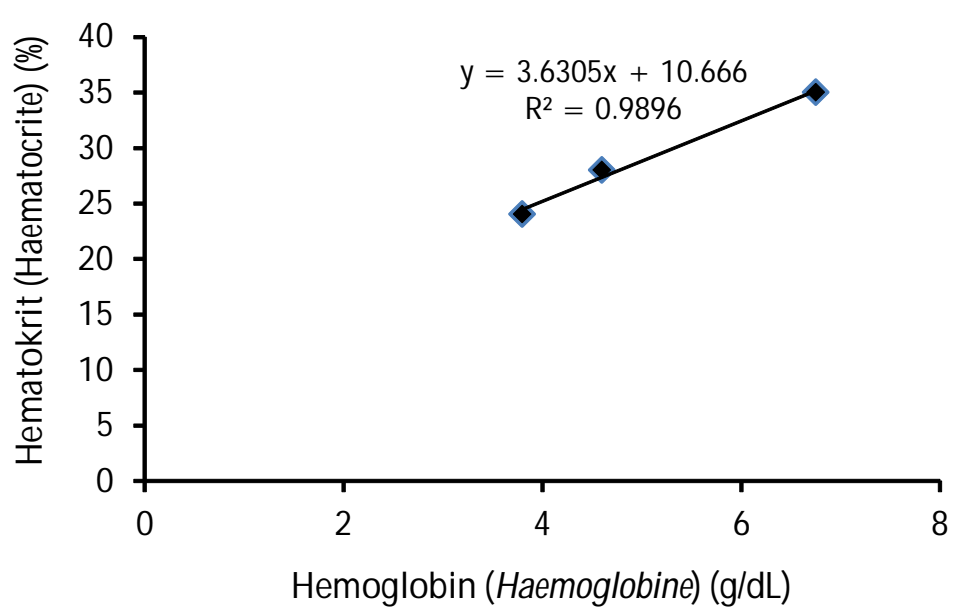

Gambar 3. Korelasi nilai haematokrit dan haemoglobin.

Figure 3. Correlation between haematocrite and haemoglobin.

meningkatkan aktivitas aerobik pada tingkat sel. Haematococcus selain berperan dalam sumber pigmen juga berperan sebagai antioksidan yang mampu mempertahankan persentase sel darah merah dan haemoglobin. Pengaruh pemberian antioksidan dari daun jeruju terbukti meningkatkan jumlah eritrosit (Agung et al., 2013) dan pada penelitian Chattopadhyay et al. (2004) tentang penggunaan kunyit yang juga memiliki aktivitas antioksidan terbukti mampu mencegah lisisnya sel darah merah.

\section{KESIMPULAN}

Berdasarkan hasil penelitian menunjukkan bahwa penambahan haematococcus sebagai sumber astaxanthin mampu mengakumulasi total karoten dalam tubuh benih dan sebagai antioksidan mampu mempertahankan profil darah kerapu sunu baik hematokrit maupun hemoglobin dalam kondisi normal. Pemberian haematococcus tanpa campuran minyak mampu meningkatkan kandungan total karoten sebesar 1,47x lebih besar dari kontrol dan mampu meningkatkan nilai hematokrit dan hemoglobin masing-masing sebesar 2,19x dan 1,78x lebih besar dari kontrol.

\section{UCAPAN TERIMA KASIH}

Penelitian ini dapat terselenggara berdasarkan anggaran APBN tahun 2016. Ucapan terima kasih kami ucapkan kepada para tim teknisi kerapu sunu yang ikut membantu dalam pelaksanaan kegiatan penelitian ini.

\section{DAFTAR ACUAN}

AbdelsameeGooda, A., Sallam, A.E., \& Srour, T.M. (2018). Evaluation of natural and synthetic caro- tenoid supplementation on growth, survival, total carotenoid content, fatty acids profile and stress resistance of European Seabass, Dicentrarchus labrax, fry. Aquaculture Studies, 18(1), 27-39.

Agung, L.A., Prayitno, S.B., \& Sarjito. (2013). Pengaruh pemberian ekstrak daun jeruju (Acanthusilicifolius) terhadap profil darah ikan kerapu macan (Epinephelus fuscoguttatus). Journal of Aquaculture Management and Technology, 2(1), 87-101.

Arimboor, R., Natarajan, R.B., Menon, K.R., Chandrasekhar, L.P., \& Moorkoth, V. (2015). Red pepper (Capsicum annuum) carotenoids as a source of natural food colors: Analysis and stability (a review). Journal of Food Scienceand Technology, 52(3), 1258-1271.

Britton, G., Liaaen-Jensen, S., \& Pfander, H. (2012). Carotenoids: Handbook. (Eds.). Washington D.C.: Birkhäuser Verlag.

Chattopadhyay, I., Biswas, K., Bandyopadhyay, U., \& Banerjee, R.K. (2004). Turmeric and curcumin: Biological actions and medicinal applications. Current Science-Bangalore, 87, 44-53.

Davis, K.B. \& Parker, N.C. (1990). Physiological stress in striped bass: Effect of acclimation temperature. Aquaculture, 91(3-4), 349-358.

Effendie, M.I. (1997). Biologi perikanan. Yogyakarta: Yayasan Pustaka Nusatama.

Fakharzadeh, S.M.E., Farhangi, M., Amiri, B.M., Ahmadi, M., \& Maloumi, N. (2011). The Effect of hydrocortisone treatment by bathing and daphnia enrichment on the salinity stress in Persian sturheon Acipenser percius juvenille. International Aquatic Research, 3, 125-133. 
Fánge, R. (1992). Fish blood cells. In Hoar, W.S., Randall, D.J., \& Farrell, A.P. Academic Press. Fish physiology, 12, 1-54.

Fiedor, J. \& Burda, K. (2014). Potential role of carotenoids as antioxidants in human health and disease. Nutrients, 6(2), 466-488.

Fujaya, Y. (2004). Fisiologi ikan: Dasar pengembangan teknik perikanan. Jakarta: Rineka Cipta.

Goodwin, T.W. (1980). Nature and distribution of carotenoids. Food Chemistry, 5(1), 3-13.

Graham, R.D. \& Rosser, J.M. (2000). Carotenoids in staple foods: Their potential to improve human nutrition. Food and Nutrition Bulletin, 21(4), 404-409.

Hrubec, T.C. \& Smith, S.A. (2000). Hematology of fish. In Feldman, B.F., Zinkl, J.G., \& Jain, N.C. Willey Blackwell: Schalm's Veterinary Hematology Fifth.

Hussein, G., Sankawa, U., Goto, H., Matsumoto, K., $\&$ Watanabe, H. (2006). Astaxanthin, a carotenoid with potential in human health and nutrition. Journal of natural products, 69(3), 443-449.

Jones, C.M. \& Grutter, A.S. (2005). Parasitic isopods (Gnathia sp.) reduce haematocrit in captive blackeye thicklip (Labridae) on the Great Barrier reef. Journal of Fish Biology, 66(3), 860-864.

Kim, Y.G., Lee, Y.H., Kang, M.K., Lee, B.H., Yun, J.K., Kim, S.B., \& Kim, C.J. (2009). Preparation of functional cosmetics containing \$beta \$-carotene derived from recombinant Escherichia coli and evaluation of anti-wrinkle efficacy by clinical testing. Microbiology and Biotechnology Letters, 37(4), 399-404.

Kusumawati, D. \& Setiawati, K.M. (2017). The use of carotene materials as the source of red color pigmentation on leo pard grouper larvae (Plectropomus leopardus). Aquacultura Indonesiana, 17(2), 35-45.

Lorenz, R.T. \& Cysewski, G.R. (2000). Commercial potential for haemato coccus microalgae as a natural source of astaxanthin. Trends in Biotechnology, 18(4), 160-167.

Mclnerney, E.P., Silla, A.J., \& Byrne, P.G. (2016). The influence of carotenoid supplementation at different life-stages on the foraging performance of the Southern Corroboree frog (Pseudophryne corroboree): A test of the silver spoon and environmental matching hypotheses. Behavioural Processes, 125, 26-33.

Meyer, D.J., Coles, E.H., \& Rich, L.J. (1992). Veterinary laboratory medicine interpretation and diagnosis. Philadelphia: W.B. Saundres Company.
Munkittrick, K.R. \& Leatherland, J.F. (1983). Haematocrit values in feral goldfish, Camssius auratus L., as indicators of the health of the population. Journal of Fish Biology, 23(2), 153-161.

Naguib, Y.M. (2000). Antioxidant activities of astaxanthin and related carotenoids. Journal of Agricultural and Food Chemistry, 48(4), 1150-1154.

Nickell, D.C. \& Bromage, N.R. (1998). The effect of lipid level on variation of flesh pigmentation in rainbow trout Oncorhynchus mykiss. Aquaculture, 161, 237-251.

Nolan, J.M., Mulcahy, R., Power, R., Moran, R., \& Howard, A.N. (2018). Nutritional intervention to prevent alzheimer's disease: Potential benefits of xanthophyll carotenoids and omega-3 fatty acids combined. Journal of Alzheimer's Disease, 64(2), 367-378.

Olaizola, M. (2003). Commercial development of microalgal biotechnology: from the test tube to the market place. Biomolecular engineering, 20(4-6), 459-466.

Pangkey, H. (2011). Kebutuhan asam lemak esensial pada ikan laut. Jurnal Perikanan dan Kelautan Tropis, 7(2), 93-102.

Salasia, S.I.O., Sulanjari, D., \& Ratnawati, A. (2001). Studi hematologi ikan air tawar. Berkala IImiah Biologi, 2(12), 710-723.

Sandnes, K., Lie, Ø., \& Waagbø, R. (1988). Normal ranges of some blood chemistry parameters in adult farmed Atlantic salmon, Salmo salar. Journal of Fish Biology, 32(1), 129-136.

Setiawati, K.M., Mahardika, K., Alit, A.K., Kusumawati, D., \& Mastuti, I. (2017). Pertumbuhan dan profil darah benih ikan kerapu sunu Plectropomus Leopardus dipelihara pada salinitas berbeda. Jurnal IImu dan Teknologi Kelautan Tropis, 9(2), 557-568.

Shah, M., Mahfuzur, R., Liang, Y., Cheng, J.J., \& Daroch, M. (2016). Astaxanthin-producing green microalga Haematococcus pluvialis: from single cell to high value commercial products. Frontiers in plant science, 7(531), 1-29.

Sultana, B., Anwar, F., \& Przybylski, R. (2007). Antioxidant potential of corncob extracts for stabilization of corn oil subjected to microwave heating. Food Chemistry, 104(3), 997-1005.

Tay-Agbozo, S., Street, S., \& Kispert, L. (2018). The carotenoid Bixin found to exhibit the highest measured carotenoid oxidation potential to date consistent with its practical protective use in cosmetics, drugs and food. Journal of 
Photochemistry and Photobiology B: Biology, 186, 1-8.

Yang, Y., Kim, B., \& Lee, J.Y. (2013). Astaxanthin structure, metabolism, and health benefits. Jounal of Human and Nutrition Food Science, 1(1003), 1-1003.

Packer, L. (1992). Carotenoids. Part A. chemistry, separation, quantitation, and autoxidation. San Diego: Academic Press. Meth. Enzymol., 213.

Yi, X., Zhang, F., Xu, W., Li, J., Zhang, W., \& Mai, K. (2014). Effects of dietary lipid content on growth, body composition and pigmentation of large yellow croaker (Larimichthys croceus). Aquaculture, 434 , 355-361. 